\title{
Identification of new protein-coding genes with a potential role in the virulence of the plant pathogen Xanthomonas euvesicatoria
}

(1) CrossMark

\author{
Ulrike Abendroth ${ }^{1 *}$ (D), Norman Adlung ${ }^{1}$, Andreas Otto ${ }^{2}$, Benjamin Grüneisen ${ }^{1,3}$, Dörte Becher ${ }^{2}$ and Ulla Bonas ${ }^{1 *}$
}

\begin{abstract}
Background: Bacteria of the genus Xanthomonas are economically important plant pathogens. Pathogenicity of Xanthomonas spp. depends on the type III-secretion system and additional virulence determinants. The number of sequenced Xanthomonas genomes increases rapidly, however, accurate annotation of these genomes is difficult, because it relies on gene prediction programs. In this study, we used a mass-spectrometry (MS)-based approach to identify the proteome of Xanthomonas euvesicatoria (Xe) strain 85-10 also known as X. campestris pv. vesicatoria, a well-studied member of plant-pathogenic Xanthomonadaceae.

Results: Using different culture conditions, MS-datasets were searched against a six-frame-translated genome database of Xe. In total, we identified 2588 proteins covering 55\% of the Xe genome, including 764 hitherto hypothetical proteins. Our proteogenomic approach identified 30 new protein-coding genes and allowed correction of the $\mathrm{N}$-termini of 50 protein-coding genes. For five novel and two $\mathrm{N}$-terminally corrected genes the corresponding proteins were confirmed by immunoblot. Furthermore, our data indicate that two putative type VIsecretion systems encoded in Xe play no role in bacterial virulence which was experimentally confirmed.

Conclusions: The discovery and re-annotation of numerous genes in the genome of Xe shows that also a wellannotated genome can be improved. Additionally, our proteogenomic analyses validates "hypothetical" proteins and will improve annotation of Xanthomonadaceae genomes, providing a solid basis for further studies.
\end{abstract}

Keywords: Xanthomonas, Proteogenome, Ortho proteogenomic, Genome re-annotation, Translational start sites, T3SS, T4SS, T6SS

\section{Background}

Since the first sequenced genome of phage $\phi X 174$ in 1978 the number of sequenced genomes has steadily increased due to the development of new and efficient sequencing methods $[1,2]$. Today, a major challenge is not the sequencing of new genomes, but the correct annotation of as many genes as possible, the basis for detailed functional analyses. Coding sequences (CDS) are usually annotated using gene prediction software such as Glimmer, Prodigal, Genemark and Easygene [3-6]. The high coding capacity (up to 90\%) of bacterial, viral and archaeal genomes [3] require a high accuracy of gene prediction programs. An important quality parameter of

\footnotetext{
*Correspondence: ulrike.abendroth@gmx.net; ulla.bonas@genetik.uni-halle.de ${ }^{1}$ Institute for Biology, Department of Genetics, Martin-Luther-Universität Halle-Wittenberg, D-06099 Halle, Germany

Full list of author information is available at the end of the article
}

prediction software is the sensitivity, i.e., how many of the known genes in a well-characterized genome are predicted [3]. One example is the $99 \%$ sensitivity of the first version of Glimmer (2.0) [7]. With respect to protein-coding genes, a major challenge is the correct prediction of the translation start sites (TSS) because homology often decreases in the vicinity of the TSS [8]. Gene annotation quality can be improved by the integration of transcriptome and, more importantly, proteome data using a massspectrometry based approach. Proteogenomics integrates shot-gun proteome information into the genome annotation process [9], thereby directly mapping MS-spectra to the six possible open reading frames. This helps to validate predicted protein-coding genes and improves genome annotation. Refinement of a given genome annotation can then be extended to related species using comparative genomics. 
Our lab studies the Gram-negative $\gamma$-proteobacterium Xanthomonas euvesicatoria strain 85-10 (Xe), also termed $X$. campestris pv. vesicatoria $[10,11]$, which causes bacterial spot disease on pepper and tomato plants [12]. The genus Xanthomonas comprises economically important pathogens that together infect a wide range of crop plant species [13]. Xe enters the plant tissue via natural openings, e.g., stomata, or wounds and multiplies locally in the intercellular space [14]. Pathogenicity of $\mathrm{Xe}$ relies on the type III-secretion system (T3SS), which is encoded by the chromosomal hrp (hypersensitive response and pathogenicity)-gene cluster $[15,16]$ and translocates bacterial effector proteins (T3E) directly into the plant cell [17]. Expression of the T3SS components is induced during infection and in special minimal media (e.g., XVM2 [18]). The key regulator HrpG, an OmpR-type response regulator is activated by unknown plant signals and controls the expression of a large hrp-regulon, including many T3E [19]. The isolation of a point mutation in $h r p G$ (termed $\left.h r p G^{*}\right)$, which renders the HrpG protein constitutively active, was key for the analysis of the T3SS and the identification of new virulence factors [20].

The genome sequence of our model $\mathrm{Xe}$ strain 85-10 was published in 2005 [12] and has a G + C-content of $64.5 \%$. Besides the $5.18 \mathrm{Mb}$ chromosome, there are four plasmids, pXCV2, pXCV19, pXCV38 and pXCV183 (1.8 kb, $19 \mathrm{~kb}, 38 \mathrm{~kb}$ and $182.5 \mathrm{~kb}$, respectively) [12]. In the original annotation, 4726 genes for proteins and functional RNAs were predicted. This number did not include yet the 24 genes for small non-protein coding RNAs (sRNAs) which were recently identified by an RNA-seq approach [21]. The latter approach also revealed unusually long 5'-UTRs for a number of T3E genes suggesting incorrectly annotated TSS. One confirmed example is the T3E XopD whose $\mathrm{N}$-terminus had to be extended by 215 amino acids (aa) [22].

Here, we propose a re-annotation of the $\mathrm{Xe} 85-10$ genome using proteogenomic data obtained in a largescale experiment. This is the first study to propose a $\mathrm{Xe}$ genome refinement, which can be extended to other economically important bacterial genera.

\section{Results}

\section{Proteogenomic analysis of $\mathrm{Xe}$ 85-10}

The overall goal of this study was to identify as many proteins as possible that are expressed in the $\mathrm{Xe}$ strain $85-10$ and its derivative $85^{*} .85^{*}$ carries a point mutation in $h r p G$ which renders the expression of the T3SS and effector genes constitutive in minimal media and complex medium NYG [20]. For MS analyses bacteria were grown to exponential and stationary phase, respectively, in three different media: NYG, minimal medium A (MA) $\mathrm{pH} 7$ and XVM2. MA and XVM2 media induce the T3SS and T3E genes [18]. Bacterial cells were ruptured by French press, and the lysates analysed as shown in the flow-sheet (Fig. 1, for details see Methods). MS/ MS analyses revealed 845,925 spectra which were assigned to peptide sequences using Sequest and an in silico translated six-frame database of Xe 85-10. The rationale behind this was the aim to cover all annotated coding sequences but also possible CDS missed in the original genome annotation [12]. Peptides were mapped to 2588 CDS thus covering $54.7 \%$ of the $\mathrm{Xe} 85-10$ genome. Please note that 2500 CDS map to the chromosome (Additional file 1) and the remaining $88 \mathrm{CDS}$ to the four Xe 85-10 plasmids. Given 1684 hypothetical CDS (termed hypothetical, or putative secreted or membrane proteins) in the originally annotated Xe 85-10 genome, we validated the expression of $764 \mathrm{CDS}$ on the protein level (45\%) (Additional file 2).

Mapping of the peptides to the six-frame genome database revealed (i) 50 protein-coding regions with a longer N-terminal region than annotated and (ii) 30 new genes (Fig. 2 and Tables 1 and 2, for additional information see Additional file 3). If the annotation would be corrected based on the new data, 32 genes would overlap now with previously annotated CDS, e.g., the newly identified protein-coding genes $X C V_{-} P G 10$ and $X C V_{-} P G 15$ (Fig. 3a), and $\operatorname{raxB}$ and XCVO251 (Fig. 3b), for which the original annotation likely has to be revisited since MS-data for the raxB protein point toward a new TSS and raxA spectra are missing.

\section{Protein coding genes with longer $\mathrm{N}$-terminal regions in $\mathrm{Xe}$}

The prediction of the most likely TSS is a critical point in genome annotations. In GC-rich genomes, $\sim 60 \%$ of genes might have a incorrectly annotated TSS [23]. To identify erroneously annotated TSS we searched for peptides located upstream of and in the same frame as a previously annotated TSS. Out of the 50 longer genes 49 are encoded on the chromosome and one on pXCV183, the largest plasmid (Table 1). Among the longer genes is $d k s A$, which now largely overlaps with XCV2557, encoded on the opposite strand (Fig. 4a) and not represented by any peptides in this study. Thus, we propose to delete XCV2557. That this appears to be justified is based on a previous transcriptome study which revealed a transcription start site for $d k s A$ overlapping with $X C V 2557$ [21]. Given the $d k s A$ transcription start site and peptides covering this genomic region our new data suggest two possible TSS (Fig. 4a). Site-directed mutagenesis of the annotated and the possible TSS revealed that protein translation most likely starts at the first GTG (Fig. 4b). Using expression constructs whose expression is driven by the native promoter, we observed not only that the first GTG is used, but also a processed 


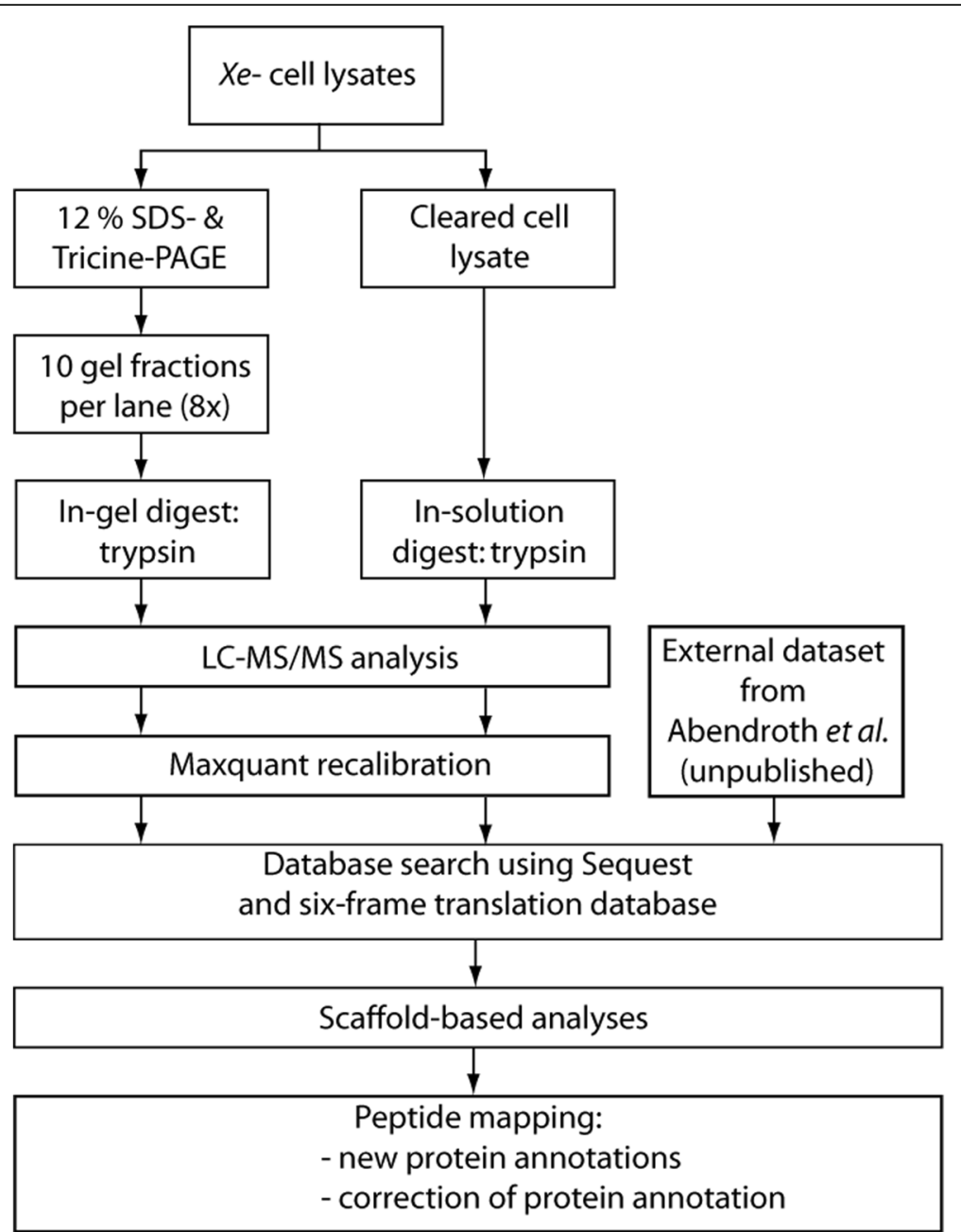

Fig. 1 Experimental workflow of the proteogenomic analysis of $X e$. The Xe strains $85-10,85^{*}$ and $85-10 \Delta$ s X 13 were grown in NYG, Minimal medium A pH 7 and $X V M 2$, respectively, at $30{ }^{\circ} \mathrm{C}$ until $\mathrm{OD}_{600}$ of either 0.5 (exponential), 0.8 (early stationary) or 1.2 (stationary). Proteins extracted from Xe 85-10, 85-10 $\Delta$ SX13 and $85^{*}$ cell lysates were separated by 12\% SDS PAGE and Tricine PAGE. Gel fractions and cell lysate were digested by trypsin. Samples were analyzed by LC-MS/MS. A database search against a six-frame translation database of Xe 85-10 was performed. Peptides were mapped to the genome of Xe using a TBlastN-based approach. The dataset from Abendroth et al. is originally a comparative study between $X e$ strains $85-10$ and $85-10 \Delta s \times 13$ and is based on the original genome annotation. The MS spectra of this dataset were also searched against the six-frame database

variant of DksA. We also experimentally analyzed TSS of XCV1265, encoding a D-alanyl-D-alanine carboxypeptidase. For $X C V 1265$, peptide data suggest a TSS further upstream than in the annotation, which was confirmed by site-directed mutagenesis (Fig. $4 \mathrm{c}$ and d).

Another example of a longer than previously thought gene is $d c p 2$ for which a peptide overlapping the annotated GTG TSS suggests an ATG start codon further upstream. This is supported by ortho-proteogenomic analysis of other members of the Xanthomonadaceae (Additional file 4). Similarly, our peptide data and an ortho-proteogenomic analysis indicate that exbB2 is incorrectly annotated (Additional file 4). Surprisingly, given the $64 \% \mathrm{G}+\mathrm{C}$ content in $\mathrm{Xe}$, we found that for infC obviously the codon ATT is used as TSS. Here, we detected peptides further upstream of the previously annotated TSS. Additional sequence analyses showed that the only possible TSS is an ATT, because there is no alternative start codon (common TSS: ATG, GTG, TTG) between the last peptide-covered sequence and the stop codon (Additional file 4). InfC is well-analyzed in other bacteria, e.g., E. coli, where the same TSS codon is used $[24,25]$.

\section{Identification and verification of novel protein-coding genes}

Intriguingly, our $\mathrm{Xe}$ proteomic approach identified 30 new genes encoding mostly small proteins with an average size of 191 amino acids (aa), ranging from 25 to 820 aa (Table 2). Among the small proteins is sX6, which 


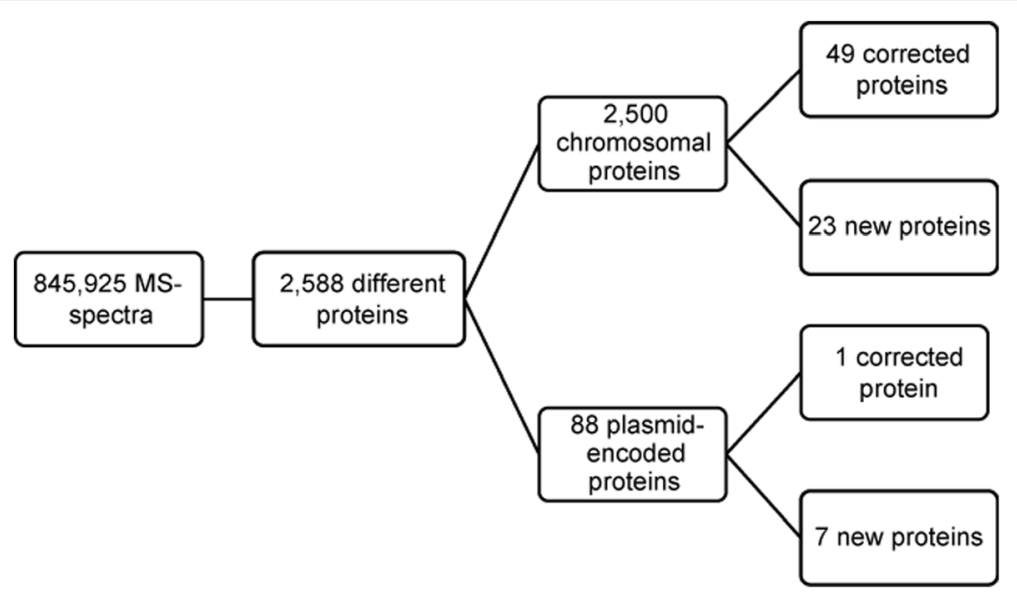

Fig. 2 Overview of proteins identified in the proteogenomic analysis of $X e$

was first assumed to act as sRNA but encodes a protein [21], which we could verify in our data. Xe harbours the 1852 bp plasmid pXCV2, which was thought to encode two protein-coding genes [26]. In this study, we detected peptides mapping to a third CDS which is located between position 1673 and 114 and encodes a protein of 60 aa (Additional file 5). Most new proteins have no annotated counterpart in other Xanthomonas genomes. However, 15 of the 30 protein-coding genes are conserved on the DNA level (Blast output: at least $80 \%$ coverage and $80 \%$ identity) suggesting that the corresponding proteins are also produced in other xanthomonads.

We predicted functional domains in the newly identified proteins. Interestingly, $X C V_{-} P G 01$, located between $X C V 0062$ and XCV0063, encodes a putative serine/ threonine phosphatase of the $2 \mathrm{C}$ family, which was previously overlooked. Furthermore, we identified a putative YecR-like lipoprotein, $X C V$ _PG06, which was recently annotated in $X$. oryzicola [27]. A special case is $X C V_{-} P G 30$, which is encoded antisense to $g c v P$, predicted to encode a metal-dependent RNase. Both corresponding proteins are represented by peptides in this study. However, most new proteins lack known functional domains.

To validate the MS-data experimentally by an independent method, the expression of five new protein-coding genes was tested. An important criterion for the selected genes was the knowledge of the exact transcription start sites [21]. C-terminal cMyc tagged expression constructs under the control of the native promoter were generated in PBRM-P and transformed into Xe 85-10. As shown in Fig. $5 \mathrm{a}$, all tested new CDS expressed proteins of expected molecular mass. In case of $X C V \_$PG02 there are five possible TSS (Fig. 5b). As the correct TSS cannot be deduced from the immunoblot it needs to be determined by alternative methods.

\section{The putative T6SS of $X e$ has no virulence function in standard virulence assays}

Since the bacteria were grown in T3SS-inducing conditions, we expected to detect peptides corresponding to known virulence factors, i.e., T3SS components and T3E. Our MS-analysis identified $69 \%$ of T3E and $84 \%$ of structural and regulatory T3SS proteins (Table 3 and Additional file 6). Furthermore, 10 of 11 known Xps type II-secretion system (T2SS) components and 3 of 5 known substrates $[28,29]$ were detected (Table 3 and Additional file 6). Xe also encodes the Xcs T2SS, which in contrast to the Xps T2SS does not contribute to virulence [28]. No components of the Xcs T2SS were detected in our study. Various components of type IVsecretion systems (T4SS) [12] and type VI-secretion systems (T6SS) are encoded in $\mathrm{Xe}$ [30], but it is unknown if these putative secretion systems are functional in $\mathrm{Xe}$. In order to identify a potential virulence function of putative T4SS and T6SS, we analyzed whether components were detected in our MS-data. Ten out of the 18 predicted components of the Vir-type T4SS were detected in our MS/MS-data, but no component of the Icm/Dot-type T4SS (Table 3 and Additional file 6). In addition, we analyzed two loci in the $X e$ genome, each encoding 15 conserved T6SS components (Fig. 6a). Only the T6SS component TssH/ClpV was detected in our MS-data (Table 3 and Additional file 6).

To test whether the putative T6SS contribute to virulence of $\mathrm{Xe}$, deletion mutants were generated. On one hand, we deleted the TssI/VgrG-encoding gene of both loci (xcv2133 and xcv4217, termed TssI1 and TssI2) and on the other hand, TssF-, TssG- and TssH/ClpV-encoding genes of both loci (XCV2125-XCV2127, termed TssFGH1 and XCV4236-XCV4238, termed TssFGH2) were deleted (Fig. 6a). In characterized T6SS these components are essential for function [31]. The generated

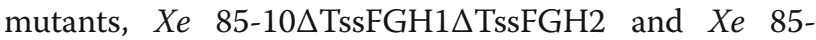


Table 1 Summary of incorrectly annotated genes

\begin{tabular}{|c|c|c|c|c|}
\hline$I^{\mathrm{a}}$ & Gene & Chromosomal/plasmid position & Detected length (aa) & Annotated length (aa) \\
\hline \multicolumn{5}{|c|}{ Erroneously annotated CDS on Xe chromosome } \\
\hline 0056329 & XCV0252 & $292545 . .293186$ & 214 & 103 \\
\hline 0056337 & $d c p 2$ & $295098 . .297215$ & 706 & 697 \\
\hline 0162384 & XCV0352 & $403872 . .404171 \mathrm{C}$ & 100 & 98 \\
\hline 0107340 & hrpD6 & $469724 . .470224$ C & 167 & 85 \\
\hline 0002631 & $x O p D$ & $486784 . .488823$ & 757 & 545 \\
\hline 0057941 & hsdS1 & $576612 . .577958$ & 449 & 419 \\
\hline 0003072 & $\operatorname{trpC}$ & $584455 . .585336$ & 294 & 265 \\
\hline 0106644 & XCV0529 & $595352 . .597223$ C & 624 & 532 \\
\hline 0030344 & XCV0537 & $602135 . .603208$ & 358 & 308 \\
\hline 0133900 & XCV0557 & $624664 . .625527 \mathrm{c}$ & 281 & 247 \\
\hline 0161114 & XCV0564 & $632247 . .633056 \mathrm{c}$ & 270 & 144 \\
\hline 0003611 & XCV0612 & $693670 . .694671$ & 334 & 326 \\
\hline 0105852 & phec & $736187 . .737158$ c & 324 & 266 \\
\hline 0032290 & XCV0855 & $974414 . .975196$ & 261 & 260 \\
\hline 0059889 & XCV0861 & $983577 . .986486$ & 968 & 660 \\
\hline 0061379 & XCV1116 & $1247631 . .1248212$ & 194 & 193 \\
\hline 0034580 & $\operatorname{rax} B$ & $1401839 . .1404616$ & 926 & 718 \\
\hline 0156885 & XCV1265 & $1423680 . .1424456$ c & 259 & 208 \\
\hline 0007939 & XCV1378 & 1558348..1558917 & 190 & 162 \\
\hline 0156077 & XCV1397 & $1577580 . .1578143 \mathrm{c}$ & 188 & 185 \\
\hline 0036069 & $d a p D$ & $1672904 . .1674070$ & 389 & 285 \\
\hline 0036594 & grpE & $1761374 . .1762582$ & 403 & 172 \\
\hline 0154666 & hutU & 1889784..1891697 C & 638 & 555 \\
\hline 0099525 & XCV1716 & $1935113 . .1936231 \mathrm{C}$ & 373 & 272 \\
\hline 0010368 & XCV1807 & $2036752 . .2038401$ & 550 & 497 \\
\hline 0098447 & XCV1885 & $2132024 . .2133079 c$ & 352 & 188 \\
\hline 0067505 & XCV2100 & $2394132 . .2395619$ & 469 & 306 \\
\hline 0125297 & $f \lg G$ & $2310361 . .2311182$ c & 274 & 261 \\
\hline 0040728 & $\operatorname{exbB2}$ & $2584091 . .2584648$ & 186 & 183 \\
\hline 0150414 & XCV2312 & $2645805 . .2646305$ C & 167 & 150 \\
\hline 0122465 & XCV2513 & $2837767 . .2838294$ C & 176 & 89 \\
\hline 0094634 & $c y d D$ & $2857544 . .2859259 \mathrm{c}$ & 572 & 570 \\
\hline 0094553 & $\arg B$ & $2874455 . .2876008$ c & 518 & 426 \\
\hline 0122245 & $d k s A$ & $2884537 . .2885304$ C & 256 & 147 \\
\hline 0093090 & gumE & $3162956 . .3164299$ c & 448 & 433 \\
\hline 0120648 & $\operatorname{infC}$ & $3173992 . .3174486$ c & 165 & 156 \\
\hline 0091857 & XCV2971 & $3378614 . .3379942$ c & 443 & 375 \\
\hline 0073386 & cheB2 & $3442416 . .3444254$ & 613 & 369 \\
\hline 0019248 & XCV 3212 & $3657508 . .3659298$ & 597 & 518 \\
\hline 0020234 & XCV3377 & $3862711 . .3863067$ & 119 & 103 \\
\hline 0075628 & XCV3419 & $3905421 . .3907445$ & 675 & 557 \\
\hline 0114862 & xps $M$ & $4216381 . .4217121 \mathrm{C}$ & 247 & 217 \\
\hline 0114852 & xpsk & $4218136 . .4219170 \mathrm{C}$ & 345 & 301 \\
\hline
\end{tabular}


Table 1 Summary of incorrectly annotated genes (Continued)

\begin{tabular}{|c|c|c|c|c|}
\hline 0114582 & $r m / D$ & $4282300 . .4283133$ c & 278 & 273 \\
\hline 0086369 & XCV3785 & $4369448 . .4371499$ c & 684 & 616 \\
\hline 0085725 & $r p o D$ & $4490900.4492780 \mathrm{c}$ & 627 & 625 \\
\hline 0078964 & rho & $4539894 . .4541690$ & 599 & 420 \\
\hline 0053728 & guaA & $4966625 . .4967413$ & 266 & 256 \\
\hline 0053999 & XCV4380 & $5042765 . .5043472$ & 236 & 222 \\
\hline \multicolumn{5}{|c|}{ Erroneously annotated CDS on Xe plasmid } \\
\hline 0166278 & XCVd0050 & $56630 . .57289$ & 220 & 217 \\
\hline
\end{tabular}

${ }^{a}$ Number of the corresponding six-frame-database entry

c chromosomal position on the minus strand

For detailed information see Additional file 3

$10 \Delta$ TssI1 $\Delta$ TssI2 were inoculated into pepper and tomato plants to test for virulence. The deletion mutants behaved like wild type, i.e., disease symptoms in susceptible plants and HR induction in resistant pepper plants (Fig. 6b). We also monitored the in planta growth of Xe $85-10 \Delta$ TssI $1 \Delta$ TssI2 in comparison to $X e$ 85-10 in leaves of susceptible pepper plants; there were no significant differences (Fig. 6c). As a control, a strain without functional T3SS (Xe 85-10 $4 h r c N)$ was used [32]. As expected, multiplication of $\mathrm{Xe} 85-10 \Delta h r c N$ was strongly reduced (Fig. 6c). Next, we additionally deleted avrBs 2 in $\mathrm{Xe} 85-10 \Delta \mathrm{TssFGH} 1 \Delta \mathrm{TssFGH} 2$. The T3E AvrBs2 is recognized in ECW-20R pepper plants [33] and is a conserved virulence factor in xanthomonads [34]. Deletion of $a v r B s 2$ renders $\mathrm{Xe}$ less virulent and helps to analyze subtle virulence effects when other genes are mutated. However, disease symptoms induced by $\mathrm{Xe}$ 85$10 \Delta$ TssFGH1 1 TssFGH2 $\Delta a v r B s 2$, in pepper ECW and tomato plants were comparable to those induced by $\mathrm{Xe}$ 85-10 $\Delta a v r B s 2$ (Fig. 6d). Taken together, deletion of conserved T6SS components did not affect virulence of $\mathrm{Xe}$ under the conditions tested.

\section{Discussion}

Because of its economical relevance, Xanthomonas spp. are currently subject of intense sequencing efforts and more and more genomes are available [35]. Here, we demonstrate the importance of proteogenomics for a better characterization of these important plant pathogens. Analyses of a large MS-spectra data set of Xe 8510 and $85^{*}$, cultivated in different media, identified 30 new genes and 50 incorrectly annotated CDS. The number of inaccuracies in the $X e$ genome annotation [12] is comparable to previous proteogenomic studies of other bacteria, e.g., Yersina, Helicobacter, Mycobacterium, Rugeria and Deinococcus [25, 36-39]. These studies led to the refinement of 4-41 new and 5-73 falsely annotated genes and reached overall genome coverage of 31$80 \%$. Thus, our study (55\%) falls into the average genome coverage. It is expected that the coverage will increase with the number of conditions tested, because proteins might be exclusively synthetized under specific conditions or below the detection limit. As our lab focusses on the analysis of proteins important for the host-pathogen interaction, we chose respective conditions, i.e., XVM2, minimal medium A pH 7 (MA 7) and $X e$ strain $85^{*}$. Identified peptides corresponded to 25 (69\%) known T3E and 21 (84\%) gene products of the hrp-gene cluster (Additional file 6). Eleven known T3E were not detected, which might be due to a low abundance within the bacterial cell. Two detected T3E, XopD und XopAA, are longer than annotated. The original $\mathrm{Xe}$ annotation stipulates that these effectors have a size of 545 aa (XopD) and 616 aa (XopAA) respectively. The MS/MS-data showed that XopD and XopAA are 215 aa and 72 aa, respectively, longer. These results are consistent with published data $[22,40]$ and corroborate the idea that unusually long $5^{\prime}$ untranslated regions in $X e$ T3E mRNAs might hint to incorrectly annotated transcription start sites $[21,22,41]$. These findings are of special importance as the $\mathrm{N}$-terminal regions of $\mathrm{T} 3 \mathrm{E}$ usually harbor the T3SS-secretion and -translocation signals [42]. The knowledge of the exact TSS is crucial for further studies of T3E.

Genome annotation inaccuracies are often due to CDS which are present in a small number of organisms, so that the power of comparative genomics is limited. Validation of longer proteins and newly identified proteins requires additional experimental evidence. In contrast to previous studies [39], we made an effort to validate novel proteins by Western blot analysis, using expression constructs controlled by the corresponding native promoter. The combined use of MS- and transcriptome data can suggest the existence of new genes, but detection of RNA alone is no proof for the existence of a CDS.

The use of the native promoter is only feasible for genes with a known transcription start site. Based on the transcriptome data of Schmidtke et al. (2012) seven expression constructs were created, and the synthesis of proteins was demonstrated by Western blot. For DksA 
Table 2 Novel genes identified in this study

\begin{tabular}{|c|c|c|c|c|}
\hline$I^{a}$ & Name & Neighboring genes & Detected protein length (aa) & Plausible protein length $(a a)^{b}$ \\
\hline \multicolumn{5}{|c|}{ New CDS found on Xe chromosome } \\
\hline 0136836 & $X C V \_P G 01$ & XCV0062-XCV0063 & 242 & 256 \\
\hline 0055942 & $X C V_{-} P G 02$ & XCV0209-XCV0210 & 114 & 116 \\
\hline 0028571 & XCV_PG03 & XCV0214-XCV0215 & 241 & 306 \\
\hline 0056540 & XCV_PG04 & XCV0282-XCV0283 & 77 & 98 \\
\hline 0065083 & XCV_PG05 & parE-pyrG & 25 & 59 \\
\hline 0094126 & $X C V \_P G 06$ & XCV2618-XCV2619 & 76 & 107 \\
\hline 0043902 & $X C V \_P G 07$ & XCV2723-XCV2724 & 42 & 70 \\
\hline 0089084 & XCV_PG08 & XCV3389-virB6 & 111 & 161 \\
\hline 0020369 & XCV_PG09 & XCV3391-XCV3392 & 73 & 141 \\
\hline 0143360 & $X C V \_P G 10$ & XCV3494 & 47 & 117 \\
\hline 0087222 & $X C V \_P G 11$ & XCV3657-xpsD & 59 & 99 \\
\hline 0022971 & $X C V \_P G 12$ & XCV3783-XCV3784 & 150 & 191 \\
\hline 0050568 & XCV_PG13 & rsmC-XCV3801 & 131 & 157 \\
\hline 0112004 & $X C V \_P G 14$ & kefC-XCV4167 & 125 & 148 \\
\hline 0111304 & $X C V \_P G 15$ & $x y \mid B 2-X C V 4282$ & 65 & $\neq$ \\
\hline 0081693 & $X C V \_P G 16$ & XCV4416-XCV4417 & 112 & 141 \\
\hline \multicolumn{5}{|c|}{ New CDS found on Xe plasmids } \\
\hline 0175626 & $X C V \_P G 17$ & after XCVa0002 & 53 & 60 \\
\hline 0173148 & $X C V \_P G 18$ & before XCVc0001 & 34 & 109 \\
\hline 0172926 & XCV_PG19 & tnpR-XCVc0009 & 74 & 76 \\
\hline 0174118 & $X C V \_P G 20$ & XCVc0025-XCVc0026 & 123 & 138 \\
\hline 0169438 & $X C V \_P G 21$ & XCVd0054-XCVd0055 & 92 & 132 \\
\hline 0166803 & $X C V \_P G 22$ & XCVd0124-XCVd0125 & 107 & 129 \\
\hline \multicolumn{5}{|c|}{ New CDS found antisense to annotated CDS } \\
\hline 0152041 & XCV_PG23 & anti-XCV2096t & 30 & 39 \\
\hline 0122029 & $X C V \_P G 24$ & anti-XCV2593t & 258 & 258 \\
\hline 0049655 & $X C V \_P G 25$ & anti-xadA1t & 1552 & 1597 \\
\hline 0080326 & $X C V \_P G 26$ & anti-XCV4209t & 200 & 203 \\
\hline 0166979 & $X C V \_P G 27$ & anti-XCVd0155t & 41 & 51 \\
\hline 0013218 & $X C V \_P G 28$ & anti-glk $7^{*}$ & 143 & 162 \\
\hline 0008300 & $X C V \_P G 29$ & anti-XCV1454* & 508 & $\ddagger$ \\
\hline 0007106 & $X C V \_P G 30$ & anti-gcvP* & 820 & 837 \\
\hline
\end{tabular}

${ }^{a}$ Number of the corresponding six-frame-database entry

† no MS-data for the annotated protein detected

* MS-data for the annotated protein detected

${ }^{b}$ Protein length till the next plausible translation start site (ATG, GTG, TTG)

\# No plausible translation start site (ATG, GTG, TTG) between detected peptide and the next upstream stop codon

For detailed information see Additional file 3

and XCV1265 we detected signals corresponding to proteins with higher molecular weight than previously annotated and confirmed the respective TSS using sitedirected mutagenesis. The transcription of $d k s A$ starts within XCV2557 [21], encoded on the opposite strand (Fig. 4a). We propose that the previously annotated gene $X C V 2557$ next to $d k s A$, for which peptide data are missing, does not exist, as it greatly overlaps with the newly proposed annotation of $d k s A$. As for $d k s A, X e$ harbors many other transcription start sites internal of proteincoding regions which might be a hint for annotation mistakes.

Furthermore, we propose that the infC translation does not start with the annotated ATG, but with ATT. An ATT start codon was also found in a proteogenomic study of Deinococcus deserti [25]. Interestingly, the 


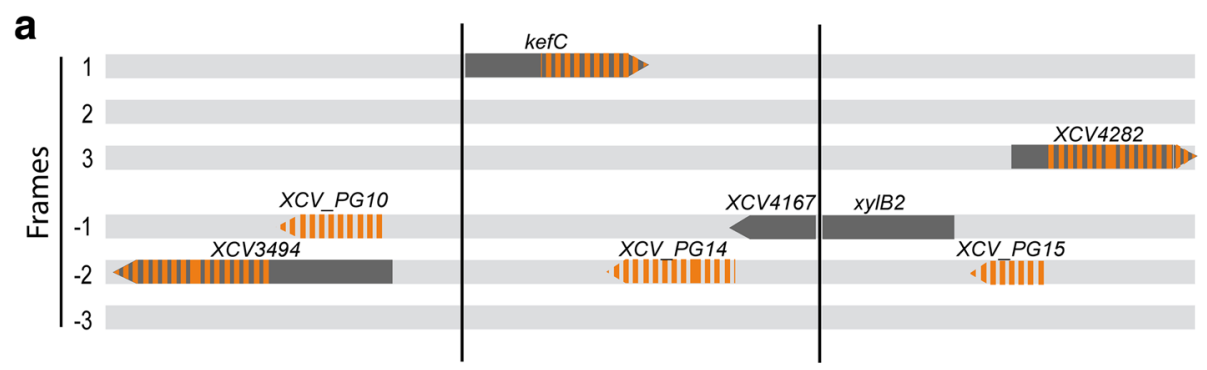

b

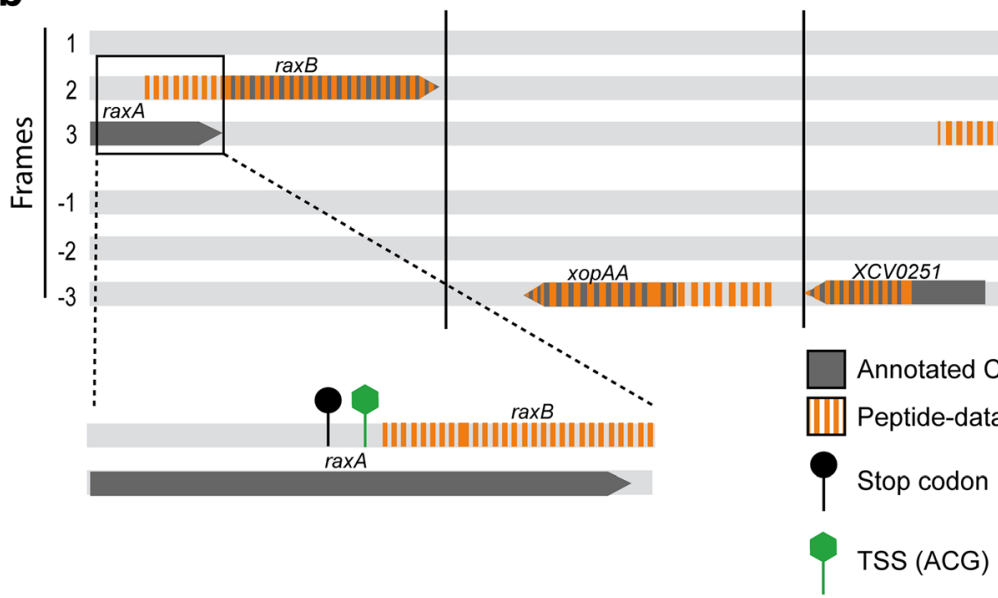

Fig. 3 Schematic overview of chromosomal regions with detected new and corrected protein-coding genes. a Examples of three new protein-coding genes detected by proteogenomics, XCV_PG10, XCV_PG14 and XCV_PG15. $\mathbf{b}$ Examples of three corrected protein-coding genes detected by proteogenomics with a close-up of the raxA/B region. All six reading frames are shown. Grey: annotated CDS; orange dashes represent peptide-data detected by MS/MS. Black circle represents a stop codon; the green hexagon represents the possible translation start codon of raxB

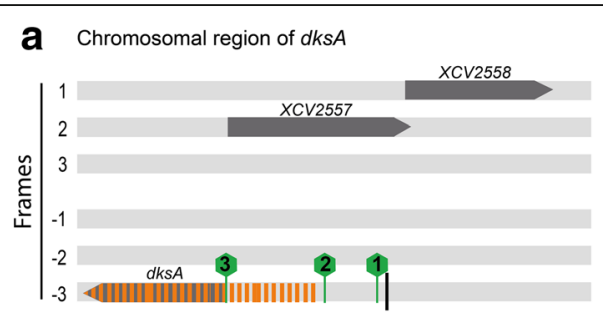

C Chromosomal region of $X C V 1265$

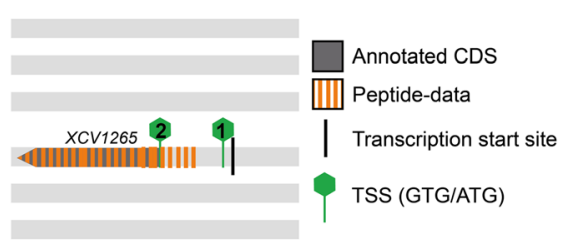

b

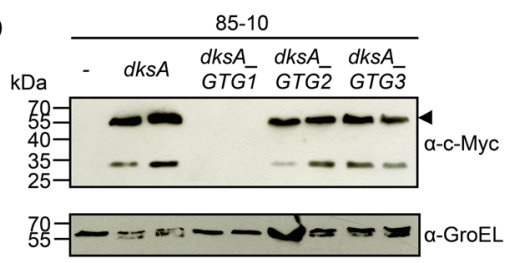

d

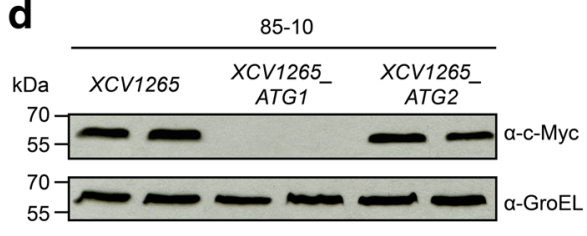

Fig. 4 Gene organization of the $d k s A$ and XCV1265 regions. a and $\mathbf{c} d k s A$ and XCV1265 loci of Xe. All six reading frames are shown. Grey: annotated CDS; orange dashes: peptide-data detected by MS/MS; green hexagons: possible translation start codons of $d k s A$ and XCV1265. b and $\mathbf{d}$ Analysis of potential translation start codons of DksA and XCV1265. Total protein extracts of Xe 85-10 containing pBRM-P(dksA), pBRM-P(dksA_GTG1), pBRM-P (dksA_GTG2), pBRM-P (dksA_GTG3), pBRM-P (XCV1265), pBRM-P (XCV1265_ATG1), pBRM-P (XCV1265_ATG2) or an empty vector (-) were separated by $12 \%$ SDS PAGE and analyzed by immunoblotting using a c-Myc-specific antibody. As loading control, membranes were reacted with a GroEL-specific antibody. Experiments were repeated at least twice with similar results 


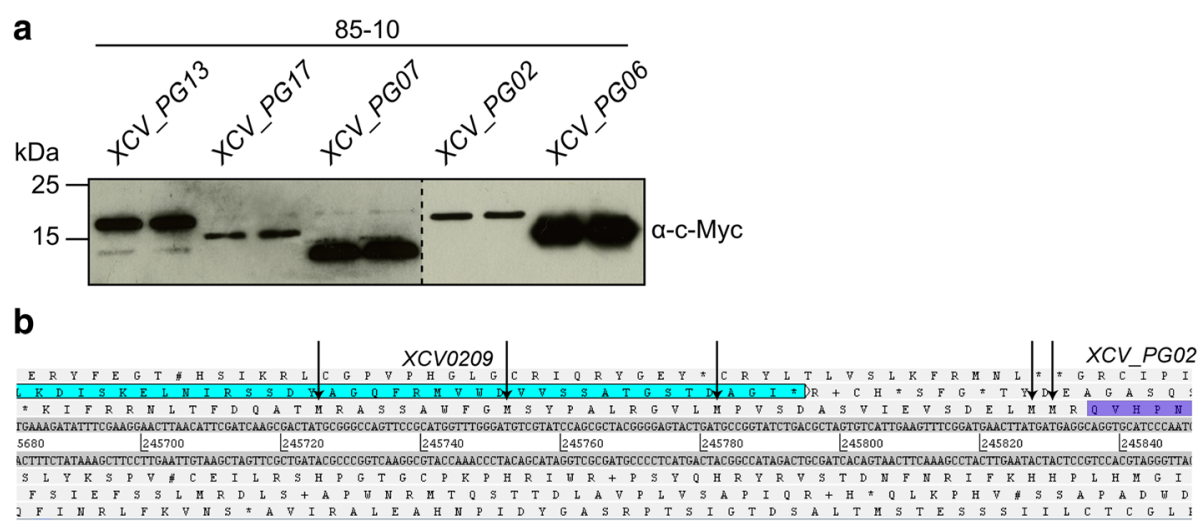

Fig. 5 Validation of five new protein-coding genes. a Detection of the protein synthesis of new Xe proteins. Total protein extracts of $X e$ 85-10 containing pBRM-P (XCV_PG13), pBRM-P (XCV_PG17), pBRM-P (XCV_PG07), pBRM-P (XCV_PG02) or pBRM-P (XCV_PG06) grown in NYG were separated by $15 \%$ SDS PAGE and analyzed by immunoblotting using a c-Myc-specific antibody. $\mathbf{b}$ Gene organization of the XCV_PG02 locus. XCV0209 and XCV_PG02 are highlighted. Arrows represent possible translation start codons of XCV_PGO2

translation of $\operatorname{infC}$ in $E$. coli is also initiated at an ATT start codon. In E. coli, the ATT start codon is used for auto-regulation of translation [24].

Besides the T3SS other secretion systems might play a role in $\mathrm{Xe}$ virulence. Our MS-analysis detected $56 \%$ of the components of a putative Vir-type T4SS. By contrast, components of the Xcs T2SS and the putative IcmDottype T4SS were not detectable. Besides $X e$, putative T4SS are encoded in many other xanthomonads, e.g., $X$. axonopodis pv. citri [43], X. citri pv. citri [44] and X. campestris $p v$. campestris [45]. The function of these systems has only been studied in a few cases. The Virtype T4SS of $X$. campestris pv. campestris does not contribute to bacterial virulence [46] and transcription of Vir-type T4SS components is downregulated during infection of host plants in X. citri pv. citri 306 [47]. In addition, the T4SS was shown to act against other

Table 3 Summary of MS/MS-data on secretion systems

\begin{tabular}{ll}
\hline Secretion system & \# of detected / known proteins \\
\hline Tat and Sec-dependent secretion & $15 / 19$ \\
T1SS & $4 / 4$ \\
T2SS - Xcs-type & $0 / 12$ \\
T2SS - Xps-type & $10 / 11$ \\
T2SS - substrates & $3 / 5$ \\
T3SS & $21 / 25$ \\
T3E & $25 / 36$ \\
T4SS - vir-type & $10 / 18$ \\
T4SS - icm-type & $0 / 15$ \\
T5-autotransporter & $3 / 4$ \\
T6SS - locus 1 & $0 / 16$ \\
T6SS - locus 2 & $1 / 16$ \\
\hline
\end{tabular}

For detailed list see Additional file 6 (Excel file)
Gram-negative bacteria in a contact-dependent manner $[44,48]$.

T6SS are encoded in many xanthomonads [30] and the genome of Xe 85-10 harbors two T6SS loci, each encoding 15 conserved T6SS components. It is not unusual that bacterial genomes harbor different T6SS loci. For example, Pseudomonas aeruginosa encodes three independent T6SS [49] and Burkholderia thailandensis five independent T6SS [50]. Only a single T6SS component was detected in our MS-approach, suggesting that both T6SS of Xe might play a role under different conditions. Since a function of a T6SS in xanthomonads is elusive, we generated mutants in putative T6SS genes in $\mathrm{Xe}$. However, the deletion mutants revealed no obvious role of the putative T6SS in the interaction with plants. The genes we deleted are predicted to result in a loss of function [31]. The T6SS of $\mathrm{Xe}$ might target other bacterial species, as shown for T6SS of Vibrio cholerea [51, 52], Serratia marcescens [53], Salmonella Typhimurium [54] and P. aeruginosa [55]. To answer this question was out of scope of this study and has to await further studies.

\section{Conclusions}

Here, we describe that the well-annotated genome of $\mathrm{Xe}$ can be improved. Besides validation of "hypothetical" proteins, we discovered novel protein-coding genes and corrected the annotation of 50 genes. Proteins of particular biological interest, e.g., a serine/threonine phosphatase, putative secreted proteins and proteins containing domains of unknown functions were identified. Furthermore, the annotation of protein-coding genes which play a role in Xanthomonas virulence have been corrected, e.g., the T3SS-component HrpD6 and the T3SS-substrate XopAA. This proteogenomic analysis will improve annotations of Xanthomonadaceae genomes. 

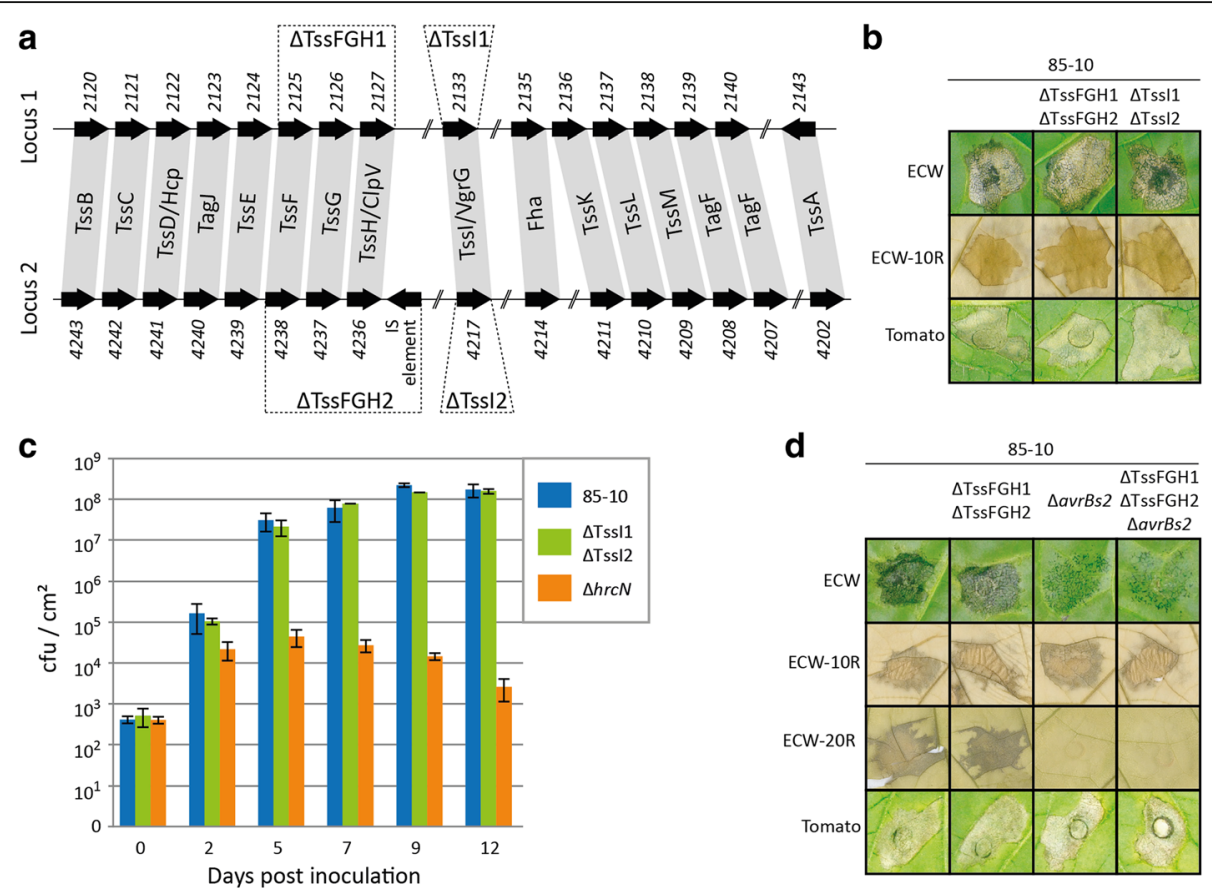

Fig. 6 Deletion of conserved T6SS components has no effect on Xe virulence. a Schematic representation of the two genomic T6SS loci in Xe. Gene numbers and commonly used gene names of T6SS components identified in Xe 85-10 are given. Dashed lines mark genes deleted in this

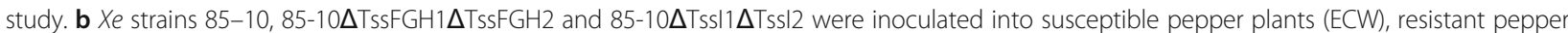
plants (ECW-10R) and susceptible tomato plants with an $\mathrm{OD}_{600}$ of 0.1. Phenotypes were documented 7 days post inoculation ( $7 \mathrm{dpi}$, ECW), $2 \mathrm{dpi}$

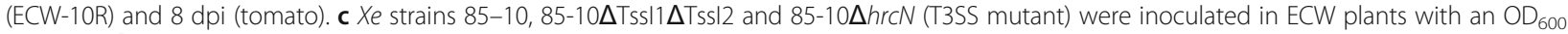
of $4 \times 10^{-5}$. Bacterial multiplication in leaves was monitored for 12 days. $\mathbf{d}$ Xe strains $85-10,85-10 \Delta T s s F G H 1 \Delta T s s F G H 2,85-10 \Delta$ avrBs2 and $85-$ $10 \Delta$ TsSFGH1 $\Delta$ TssFGH2 $\Delta$ avrBs2 were inoculated with an $\mathrm{OD}_{600}$ of 0.1 into leaves of pepper plants (ECW, ECW-10R, ECW-20R) and tomato plants. Phenotypes were documented 6 dpi (ECW), 2 dpi (ECW-10R, ECW-20R) and 9 dpi (tomato). Leaves of ECW-10R and ECW-20R plants were bleached in $\mathrm{EtOH}$ for better visualization of cell death reactions. Experiments were repeated twice with similar results

Future studies of newly identified genes might unravel new virulence functions.

\section{Methods}

\section{Bacterial strains and growth conditions}

For bacterial strains, plasmids and oligonucleotides used in this study see Additional file 7. The $X e$ strains $85-10$ $[12,56], 85^{*}$ [20] and $85-10 \Delta s X 13$ [57] were grown in NYG [58], Minimal medium A pH 7 [59] and XVM2 [18], respectively, at $30{ }^{\circ} \mathrm{C}$ until $\mathrm{OD}_{600}$ of 0.5 (exponential), 0.8 (early stationary) or 1.2 (stationary). Plasmids were introduced into $\mathrm{Xe}$ by tri-parental conjugation, using pRK2013 as helper plasmid $[60,61]$. Antibiotics were added to a final concentration of: gentamycin, $15 \mu \mathrm{g} / \mathrm{ml}$; rifampicin, $100 \mu \mathrm{g} / \mathrm{ml}, 100 \mu \mathrm{g} / \mathrm{ml}$ spectinomycin.

\section{Protein extraction and pre-separation}

Cells were cracked in TE-buffer using three times French press. Cell debris and undissolved material were removed by centrifugation $\left(15 \mathrm{~min}, 16,000 \times \mathrm{g}, 4{ }^{\circ} \mathrm{C}\right)$. Protein concentrations were measured using the Bradford assay. $100 \mu \mathrm{g}$ protein were precipitated over night with ice-cold acetone. Protein pellets were dissolved in $40 \mu \mathrm{l}$
Laemmli-buffer, and $20 \mu \mathrm{l}$ were subjected to 1-D-SDS PAGE (12\% separation gel, $4 \%$ stacking gel). The gel was fixed overnight in $40 \%$ methanol and $10 \%$ acetic acid, and stained with colloidal Coomassie (20\% Ethanol; $1.6 \%$ phosphoric acid; $8 \%$ ammonium sulfate; $0.08 \%$ Coomassie Brilliant Blue G-250).

\section{LC-MS/MS-measurements and data analysis}

Lanes of the protein gel were cut into 10 slices of equal size and proteins were digested in gel by trypsin. The eluted peptides were subjected to LC-MS/MS-analysis on a Proxeon nLC 1000 coupled to an Orbitrap Elite mass spectrometer. In-house self-packed columns (i.d. $100 \mu \mathrm{m}$, o.d. $360 \mu \mathrm{m}$, length $150 \mu \mathrm{mm}$; packed with $1.7 \mu \mathrm{m}$ Aeris XB-C18 reversed-phase material (Phenomenex, Torrance, CA, USA) were loaded, then desalted with $10 \mu \mathrm{l}$ buffer A $(0.1 \%(v / \mathrm{v})$ acetic acid $)$ at a maximum pressure of 750 bar. For LC-MS/MS-analysis, peptides were eluted using a nonlinear 80 min gradient from 1 to $99 \%$ buffer B $(0.1 \%(v / v)$ acetic acid in acetonitrile) at a constant flow rate of $300 \mathrm{nl} / \mathrm{min}$. Spectra were recorded in an Orbitrap Velos (Thermo Fisher Scientific, Waltham, MA, USA) at a resolution of 
$r=30,000$ with lockmass correction activated. After acquisition of the Full-MS-spectra, up to 20 dependent scans (MS/MS) were performed according to precursor intensity by collision-induced dissociation fragmentation (CID) in the linear ion trap.

Data were analyzed by Sorcerer Sequest against a sixframe translated database of the whole $\mathrm{Xe}$ genome (protein database containing 175,698 (21,627 $\leq 6$ aa) entries). The following search parameters were used: enzyme type, trypsin (KR); peptide tolerance, $10 \mathrm{ppm}$; tolerance for fragment ions, $1 \mathrm{Da}$; b- and y-ion series; a maximum of two modifications per peptide was allowed. Peptide and protein identifications were accepted with a false discovery rate (FDR) of maximal $0.4 \%$, requiring a minimum of at least two unique peptides for protein identification and quantification.

A second data set was generated using MS/MS-data obtained from a comparative proteome experiment. The tryptic digests obtained from the 1-D-SDS PAGE gel pieces were subjected to reversed phase column chromatography (Waters BEH $1.7 \mu \mathrm{m}, 100 \mu \mathrm{m}$ i. d. $\times 100 \mathrm{~mm}$, Waters Corporation, Milford, MA, USA) operated on a nanoACQUITY-UPLC (Waters Corporation, Milford, MA, USA). Peptides were concentrated and desalted on a trapping column (Waters nanoACQUITY UPLC column, Symmetry C18, $5 \mu \mathrm{m}, 180 \mu \mathrm{m} \times 20 \mathrm{~mm}$, Waters Corporation, Milford, MA, USA) for 3 min at a flow rate of $1 \mathrm{ml} / \mathrm{min}$ with $99 \%$ buffer A (0.1\% acetic acid). Subsequently, the peptides were eluted and separated using a non-linear 80-min gradient from 5 to $60 \% \mathrm{ACN}$ in $0.1 \%$ acetic acid at a constant flow rate of $400 \mathrm{nl} / \mathrm{min}$. MS and MS/MS-data were obtained using the LTQ-Orbitrap mass spectrometer (Thermo Fisher Scientific, Waltham, MA, USA) equipped with a nanoelectrospray ion source. After a survey scan in the Orbitrap $(r=30,000)$ with the lockmass option enabled, MS/MS-data were recorded for the five most intensive precursor ions in the linear ion trap. Singly charged ions were not taken into account for MS/MS-analysis.

Data were analyzed by Sorcerer Sequest against the 6frame database. The following search parameters were used: enzyme type, trypsin (KR); peptide tolerance, $10 \mathrm{ppm}$; tolerance for fragment ions, $1 \mathrm{Da}$; b- and y-ion series; a maximum of two modifications per peptide was allowed. Peptide and protein identifications were accepted with a false discovery rate below $1 \%$, requiring a minimum of at least two unique peptides for protein identification and quantification.

\section{Peptide mapping and visualization}

Identified peptides were mapped to the $X e$ genome using TBlastN [62], perfect and full length sequence matches were used. With this setup the best fit for the peptide to the $X e$-DNA sequence was selected. The peptides were visualized in Artemis genome browser [63]. GFF files can be found in Additional file 8 .

\section{Generation and mutation of expression constructs}

For expression in $\mathrm{Xe}$, protein coding sequences and the putative promoter region of $X C V_{-} P G 02, X C V_{-} P G 06$, $X C V_{-} P G 07, X C V_{-} P G 13, X C V_{-} P G 17, d k s A$ and $X C V 1265$ were amplified from genomic DNA of $X e$ 85-10 by PCR using oligonucleotides listed in Table 3 and cloned into pBRM-P [64] by Golden Gate cloning [65]. pBRM-P encodes a c-Myc epitope which is fused to the $3^{\prime}$ end of the insert.

To mutate possible TSS, site-directed mutagenesis was employed. For this, pBRM-P (XCV1265) or pBRM-P $(d k s A)$ were used as a template and PCR amplified using oligonucleotides harboring the desired mutation (Additional file 7). Primers carried a $5^{\prime}$ phosphate for subsequent circulation of amplicons.

\section{Protein analysis}

To analyze the protein synthesis of XCV_PG02, XCV_PG06, XCV_PG07, XCV_PG13, XCV_PG17, DksA and XCV1265 Xe 85-10 bacteria with corresponding expression constructs were grown overnight in NYG medium until stationary phase. Protein extracts were analyzed by SDS-PAGE and immunoblotting using first an antibody specific for the c-Myc epitope (Santa Cruz Biotechnology, Dallas, TX, USA) and secondly, anti-GroEL (Enzo Life Sciences, Farmingdale, NY, USA). Secondary antibodies were horseradish peroxidase labeled antimouse or anti-rabbit antibodies (GE Healthcare, Chicago, IL, USA). Antibody reactions were visualized by enhanced chemiluminescence.

\section{Generation of deletion mutants}

To generate deletion mutants, regions of about $1 \mathrm{~kb}$ flanking of the deleted sequences were amplified by PCR and cloned into the suicide vectors pOGG2 via Golden Gate cloning or pOKI via classical cloning (Table 3). An IS-element is encoded subsequently before XCV4236 $(\mathrm{TssH} / \mathrm{ClpV})$, which was deleted together with XCV4236-XCV4238 (TssFGH2), pOGG2 derivatives or pOKI (avrBs2) were conjugated into $\mathrm{Xe}$ and mutants were selected by PCR.

\section{Plant infection assays}

Plants were grown in the greenhouse with $23{ }^{\circ} \mathrm{C} / 25{ }^{\circ} \mathrm{C}$ day temperature (tomato/pepper) and $19{ }^{\circ} \mathrm{C}$ night temperature, $16 \mathrm{~h}$ of light and $40-60 \%$ humidity. For plant infection assays, $\mathrm{Xe}$ suspended in $10 \mathrm{mM} \mathrm{MgCl}$ were inoculated with a needleless syringe into leaves of the nearisogenic pepper (Capsicum annuum) cultivars ECW, ECW-10R or ECW-20R or tomato (Solanum lycopersicum) cultivar MoneyMaker [33, 66]. Pepper ECW is a 
commercial cultivar that has been used to introgress disease resistance genes and generate near-isogenic lines [33]. The tomato and pepper plants were grown as described before [56, 67].

\section{Additional files}

Additional file 1: Proteogenomic identification of proteins in Xe 85-10. Overview of the Xe chromosome showing all annotated and MS-data based identified protein-coding genes. Black: annotated CDS plus strand, Red: annotated CDS minus strand, Black-Red: MS-data based identified CDS, Black serrates line: GC-content. (PNG 133 kb)

Additional file 2: Identification of all detected proteins and their annotated function. List of all detected annotated proteins in MS-data and their predicted functions. (XLSX $693 \mathrm{~kb}$ )

Additional file 3: Additional information to Tables 1 and 2 and all conditions and strains used in this study. The tables show additional information, e.g. predicted function, homology and transcription start site, of the new and falsely incorrectly annotated protein-coding genes and all conditions and strains used in this study. (XLSX $29 \mathrm{~kb}$ )

Additional file 4: Reannotation of $d c p 2$, exbB2, flgG and infC. Multiple sequence alignment of $d c p 2$, exbB2, flgG and infC homologs of $X e, X$. axonopodis pv. citrumelo F1 (XacF1), X. oryzae pv. oryzae KACC10331 (Xoo), X. oryzae pv. oryzicola BLS256 (Xoc), X. fuscans subsp. aurantifolii ICPB 11122 (Xfa), X. perforans 91-118 (Xp). Green: experimentally detected by MS, underlined in red: annotated start codons, underlined in green: possible new start codon. (PNG $836 \mathrm{~kb}$ )

Additional file 5: $p X C V 2$ carries a third CDS. Representation of pXCV2 plasmid of Xe 85-10. Grey arrows show position of annotated CDS and the red arrow indicates the position of the newly identified proteincoding CDS. (PNG $88 \mathrm{~kb})$

Additional file 6: Detection of proteins which are components or substrates of (potential) secretion systems. +: specific peptide detected, -: no specific peptide detected in MS-data. (XLSX $15 \mathrm{~kb}$ )

Additional file 7: Oligonucleotides, plasmids and strains used in this study. List of oligonucleotides, plasmids and strains used in this study. (DOCX $45 \mathrm{~kb}$ )

Additional file 8: GFF annotation file. GFF annotation file for artemis genome browser. (TXT $147 \mathrm{~kb}$ )

\section{Abbreviations}

aa: Amino acid; CDS: Coding sequence; Da: Dalton; ECW: Early cal wonder; FDR: False discovery rate; GFF: General feature format; LC: Liquid chromatography; MA: Mini medium A; MS: Mass spectrometry; sRNA: Small RNA; T2SS: Type II secretion system; T3E: Type III effector; T3SS: Type III secretion system; T4SS: Type IV - secretion system; T6SS: Type VI - secretion system; TSS: Translation start site; UTR: Untranslated region

\section{Acknowledgements}

We thank Alexander Schröder, Hannelore Espenhahn and Bianca Rosinsky for excellent technical assistance and Johannes Stuttmann and Cornelius Schmidtke for helpful discussions.

\section{Funding}

The work was supported by grands from the Deutsche Forschungsgemeinschaft as part of the priority program 'Sensory and Regulatory RNAs in Prokaryotes (SPP 1258) and the Gottfried Wilhelm Leibniz-Preis to UB. The funding bodies were not involved in the planning and execution of the study.

\section{Availability of data and materials}

The mass spectrometry proteomics data have been deposited to the ProteomeXchange Consortium via the PRIDE $[68,69]$ partner repository with the dataset identifier PXD007140.

\section{Authors' contributions}

UA and UB planned experimental approach. AO and DB performed mass spectrometry of protein samples, delivered by UA. UA, together with $B G, A O$ and $\mathrm{DB}$, analyzed MS-data. UA interpreted MS-data and validated new and re-annotated proteins. NA characterized the T6SS. UA prepared the manuscript with contribution from NA and UB and all authors reviewed the manuscript. All authors read and approved the final manuscript.

\section{Ethics approval and consent to participate}

There is no permission needed to work with the pepper and tomato plants used in this study. The plants are commercially used and were bred and published. There are no local guidelines restricting the use of the plants used in this study.

\section{Consent for publication}

Not applicable.

\section{Competing interests}

The authors declare that they have no competing interests.

\section{Publisher's Note}

Springer Nature remains neutral with regard to jurisdictional claims in published maps and institutional affiliations.

\section{Author details}

Institute for Biology, Department of Genetics, Martin-Luther-Universität Halle-Wittenberg, D-06099 Halle, Germany. ${ }^{2}$ Institute for Microbiology, Department of Mass Spectrometry, Ernst-Moritz-Arndt-Universität, D-17487 Greifswald, Germany. ${ }^{3}$ Department of Psychiatry and Psychotherapy, Martin-Luther-Universität Halle-Wittenberg, D-06097 Halle, Germany.

Received: 3 April 2017 Accepted: 8 August 2017

Published online: 16 August 2017

References

1. Sanger F, Coulson AR, Friedmann T, Air GM, Barrell BG, Brown NL, et al. The nucleotide sequence of bacteriophage phiX174. J Mol Biol. 1978;125(2):22546.

2. Médigue C, Danchin A. Annotating bacterial genomes. Mod Genome Annotation. 2008:165-90

3. Delcher AL, Bratke KA, Powers EC, Salzberg SL. Identifying bacterial genes and endosymbiont DNA with glimmer. Bioinformatics. 2007;23(6):673-9.

4. Hyatt D, Chen G-L, LoCascio PF, Land ML, Larimer FW, Hauser LJ. Prodigal: prokaryotic gene recognition and translation initiation site identification. BMC Bioinform. 2010;11(1):119.

5. Besemer J, Borodovsky M. GeneMark: web software for gene finding in prokaryotes, eukaryotes and viruses. Nucleic Acids Res. 2005;33(Web Server issue):W451-4

6. Larsen TS, Krogh A. EasyGene-a prokaryotic gene finder that ranks ORFs by statistical significance. BMC Bioinform. 2003:4(1):21.

7. Salzberg SL, Delcher AL, Kasif S, White O. Microbial gene identification using interpolated Markov models. Nucleic Acids Res. 1998;26(2):544-8.

8. Besemer J, Lomsadze A, Borodovsky M. GeneMarkS: a self-training method for prediction of gene starts in microbial genomes. Implications for finding sequence motifs in regulatory regions. Nucleic Acids Res. 2001;29(12):260718.

9. Renuse S, Chaerkady R, Pandey A. Proteogenomics. Proteomics. 2011;11(4): $620-30$

10. Jones JB, Lacy GH, Bouzar H, Stall RE, Schaad NW. Reclassification of the xanthomonads associated with bacterial spot disease of tomato and pepper. Syst Appl Microbiol. 2004;27(6):755-62.

11. Barak JD, Vancheva T, Lefeuvre P, Jones JB, Timilsina S, Minsavage GV, et al. Whole-genome sequences of Xanthomonas euvesicatoria strains clarify taxonomy and reveal a stepwise erosion of type 3 effectors. Front Plant Sci. $2016 ; 71805$

12. Thieme F, Koebnik R, Bekel T, Berger C, Boch J, Büttner D, et al. Insights into genome plasticity and pathogenicity of the plant pathogenic bacterium Xanthomonas campestris pv. Vesicatoria revealed by the complete genome sequence. J Bacteriol. 2005;187(21):7254-66.

13. Leyns F, De Cleene M, Swings J-G, De Ley J. The host range of the genus Xanthomonas. Bot Rev. 1984;50(3):308-56. 
14. Büttner $D$, Bonas $U$. Regulation and secretion of Xanthomonas virulence factors. FEMS Microbiol Rev. 2010;34(2):107-33.

15. Bonas U, Schulte R, Fenselau S, Minsavage GV, Staskawicz BJ, Stall RE. Isolation of a gene cluster from Xanthomonas campestris $\mathrm{pv}$. vesicatoria that determines pathogenicity and the hypersensitive response on pepper and tomato. Mol Plant-Microbe Interact. 1991:4(1):81-8.

16. Fenselau S, Balbo I, Bonas U. Determinants of pathogenicity in Xanthomonas campestris pv. vesicatoria are related to proteins involved in secretion in bacterial pathogens of animals. Mol Plant-Microbe Interact. 1992:5(5):390-6.

17. Bonas U, Van den Ackerveken G, Büttner D, Hahn K, Marois E, Nennstiel D, et al. How the bacterial plant pathogen Xanthomonas campestris pv. vesicatoria conquers the host. Mol Plant Pathol. 2000;1(1):73-6.

18. Wengelnik K, Marie C, Russel M, Bonas U. Expression and localization of HrpA1, a protein of Xanthomonas campestris pv. Vesicatoria essential for pathogenicity and induction ofthe hypersensitive reaction. J Bacteriol. 1996a;178(4):1061-9.

19. Wengelnik K, Van den Ackerveken G, Bonas U. HrpG, a key hrp regulatory protein of Xanthomonas campestris pv. vesicatoria is homologous to twocomponent response regulators. Mol Plant-Microbe Interact. 1996b;9(8):70412.

20. Wengelnik K, Rossier O, Bonas U. Mutations in the regulatory gene hrpG of Xanthomonas campestris pv. Vesicatoria result in constitutive expression of all hrp genes. J Bacteriol. 1999;181(21):6828-31.

21. Schmidtke C, Findeiß S, Sharma CM, Kuhfuß J, Hoffmann S, Vogel J, et al Genome-wide transcriptome analysis of the plant pathogen Xanthomonas identifies sRNAs with putative virulence functions. Nucleic Acids Res. 2012; 40(5):2020-31.

22. Canonne J, Marino D, Noël LD, Arechaga I, Pichereaux C, Rossignol M, et al. Detection and functional characterization of a 215 amino acid N-terminal extension in the Xanthomonas type III effector XopD. PLoS One. 2010;5(12): e15773.

23. Nielsen $P$, Krogh A. Large-scale prokaryotic gene prediction and comparison to genome annotation. Bioinformatics. 2005;21(24):4322-9.

24. Butler JS, Springer M, Grunberg-Manago M. AUU-to-AUG mutation in the initiator codon of the translation initiation factor IF3 abolishes translationa autocontrol of its own gene (infC) in vivo. Proc Natl Acad Sci U S A. 1987; 84(12):4022-5.

25. Baudet M, Ortet P, Gaillard JC, Fernandez B, Guérin P, Enjalbal C, et al. Proteomics-based refinement of Deinococcus deserti genome annotation reveals an unwonted use of non-canonical translation initiation codons. Mol Cell Proteomics. 2010;9(2):415-26.

26. Wu L-T, Tseng Y-H. Characterization of the IncW cryptic plasmid pXV2 from Xanthomonas campestris pv. Vesicatoria. Plasmid. 2000;44(2):163-72.

27. Niu XN, Wei ZQ, Zou HF, Xie GG, Wu F, Li KJ, et al. Complete sequence and detailed analysis of the first indigenous plasmid from Xanthomonas oryzae pv. oryzicola. BMC Microbiol. 2015;15:233.

28. Szczesny R, Jordan M, Schramm C, Schulz S, Cogez V, Bonas U, et al. Functional characterization of the Xcs and Xps type II secretion systems from the plant pathogenic bacterium Xanthomonas campestris pv. vesicatoria. New Phytol. 2010;187(4):983-1002.

29. Solè M, Scheibner F, Hoffmeister AK, Hartmann N, Hause G, Rother A, et al. Xanthomonas campestris pv. vesicatoria secretes proteases and xylanases via the Xps-type II secretion system and outer membrane vesicles. J Bacteriol. 2015;197(17):2879-93.

30. Boyer F, Fichant G, Berthod J, Vandenbrouck Y, Attree I. Dissecting the bacterial type $\mathrm{VI}$ secretion system by a genome wide in silico analysis: what can be learned from available microbial genomic resources? BMC Genomics. 2009;10(1):104.

31. Cianfanelli FR, Monlezun L, Coulthurst SJ. Aim, load, fire: the type VI secretion system, a bacterial nanoweapon. Trends Microbiol. 2016;24(1):51-62.

32. Lorenz C, Büttner D. Functional characterization of the type III secretion ATPase HrcN from the plant pathogen Xanthomonas campestris pv. vesicatoria. J Bacteriol. 2009;191(5):1414-28.

33. Minsavage G, Dahlbeck D, Whalen M, Kearney B, Bonas U, Staskawicz B, et al. Gene-for-gene relationships specifying disease resistance in Xanthomonas campestris pv. vesicatoria-pepper interactions. Mol Plant-Microbe Interact. 1990;3(1):41-7.

34. Kearney B, Staskawicz BJ. Widespread distribution and fitness contribution of Xanthomonas campestris avirulence gene avrBs2. Nature. 1990;346:385-6.
35. Schwartz AR, Potnis N, Timilsina S, Wilson M, Patane J, Martins Jr. J, et al Phylogenomics of Xanthomonas field strains infecting pepper and tomato reveals diversity in effector repertoires and identifies determinants of host specificity. Front Microbiol. 2015. doi:10.3389/fmicb.2015.00535.

36. Payne SH, Huang S-T, Pieper R. A proteogenomic update to Yersinia: enhancing genome annotation. BMC Genomics. 2010;11(1):460.

37. Müller SA, Findeiß S, Pernitzsch SR, Wissenbach DK, Stadler PF, Hofacker IL, et al. Identification of new protein coding sequences and signal peptidase cleavage sites of Helicobacter pylori strain 26695 by proteogenomics. J Proteome. 2013;86:27-42.

38. Kelkar DS, Kumar D, Kumar P, Balakrishnan L, Muthusamy B, Yadav AK, et al. Proteogenomic analysis of Mycobacterium tuberculosis by high resolution mass spectrometry. Mol Cell Proteomics. 2011;10(12):M111.011627.

39. Christie-Oleza JA, Miotello G, Armengaud J. High-throughput proteogenomics of Ruegeria pomeroyi: seeding a better genomic annotation for the whole marine Roseobacter clade. BMC Genomics. 2012;13:73.

40. Tsuge S, Furutani A, Ikawa Y. Regulatory network of hrp gene expression in Xanthomonas oryzae pv. oryzae. J Gen Plant Pathol. 2014;80(4):303-13.

41. Morales C, Posada J, Macneale E, Franklin D, Rivas I, Bravo M, et al. Functional analysis of the early chlorosis factor gene. Mol Plant-Microbe Interact. 2005;18(5):477-86.

42. Büttner D. Protein export according to schedule: architecture, assembly, and regulation of type III secretion systems from plant- and animal-pathogenic bacteria. Microbiol Mol Biol Rev. 2012;76(2):262-310.

43. Alegria MC, Souza DP, Andrade MO, Docena C, Khater L, Ramos CH, et al. Identification of new protein-protein interactions involving the products of the chromosome- and plasmid-encoded type IV secretion loci of the phytopathogen Xanthomonas axonopodis pv. Citri. J Bacteriol. 2005;187(7): 2315-25.

44. Souza DP, Andrade MO, Alvarez-Martinez CE, Arantes GM, Farah CS, Salinas RK. A component of the Xanthomonadaceae type IV secretion system combines a VirB7 motif with a N0 domain found in outer membrane transport proteins. PLoS Pathog. 2011;7(5):e1002031.

45. Qian W, Jia Y, Ren S-X, He Y-Q, Feng J-X, Lu L-F, et al. Comparative and functional genomic analyses of the pathogenicity of phytopathogen Xanthomonas campestris pv. campestris. Genome Res. 2005;15(6):757-67.

46. He Y-Q, Zhang L, Jiang B-L, Zhang Z-C, Xu R-Q, Tang D-J, et al. Comparative and functional genomics reveals genetic diversity and determinants of host specificity among reference strains and a large collection of Chinese isolates of the phytopathogen Xanthomonas campestris pv. campestris. Genome Biol. 2007;8(10):R218

47. Jacob TR, Laia MLd, Moreira LM, Gonçalves JF, Carvalho FMdS, Ferro MIT, et al. Type IV secretion system is not involved in infection process in citrus. Int J Microbiol. 2014;2014:763575.

48. Souza DP, Oka GU, Alvarez-Martinez CE, Bisson-Filho AW, Dunger G, Hobeika L, et al. Bacterial killing via a type IV secretion system. Nat Commun. 2015;6: 6453

49. Sana TG, Berni B, Bleves S. The T6SSs of Pseudomonas aeruginosa strain PAO1 and their effectors: beyond bacterial-cell targeting. Front Cell Infect Microbiol. 2016;6:61.

50. Schwarz S, West TE, Boyer F, Chiang W-C, Carl MA, Hood RD, et al. Burkholderia type $\mathrm{VI}$ secretion systems have distinct roles in eukaryotic and bacterial cell interactions. PLoS Pathog. 2010;6(8):e1001068.

51. Maclntyre DL, Miyata ST, Kitaoka M, Pukatzki S. The Vibrio cholerae type VI secretion system displays antimicrobial properties. Proc Natl Acad Sci U S A 2010;107(45):19520-4.

52. Fu Y, Waldor MK, Mekalanos JJ. Tn-Seq analysis of Vibrio cholerae intestinal colonization reveals a role for T6SS-mediated antibacterial activity in the host. Cell Host Microbe. 2013;14(6):652-63.

53. Murdoch SL, Trunk K, English G, Fritsch MJ, Pourkarimi E, Coulthurst SJ. The opportunistic pathogen Serratia marcescens utilizes type VI secretion to target bacterial competitors. J Bacteriol. 2011;193(21):6057-69.

54. Sana TG, Flaugnatti N, Lugo KA, Lam LH, Jacobson A, Baylot V, et al. Salmonella Typhimurium utilizes a T6SS-mediated antibacterial weapon to establish in the host gut. Proc Natl Acad Sci U S A. 2016;113(34):E5044-51.

55. Jiang F, Waterfield NR, Yang J, Yang G, Jin Q. A Pseudomonas aeruginosa type $\mathrm{VI}$ secretion phospholipase $\mathrm{D}$ effector targets both prokaryotic and eukaryotic cells. Cell Host Microbe. 2014;15(5):600-10.

56. Bonas U, Stall RE, Staskawicz B. Genetic and structural characterization of the avirulence gene avrBs3 from Xanthomonas campestris pv. vesicatoria. Mol Gen Genet. 1989;218(1):127-36. 
57. Schmidtke C, Abendroth U, Brock J, Serrania J, Becker A, Bonas U. Small RNA sX13: a multifaceted regulator of virulence in the plant pathogen Xanthomonas. PLoS Pathog. 2013;9(9):e1003626.

58. Daniels MJ, Barber CE, Turner PC, Sawczyc MK, Byrde RJ, Fielding AH. Cloning of genes involved in pathogenicity of Xanthomonas campestris pv. campestris using the broad host range cosmid pLAFR1. EMBO J. 1984;3(13): 3323-8.

59. Ausubel F, Brent R, Kingston R, Moore D, Seidman J, Smith J, et al. Current Protocols in Molecular Biology. New York: John Wiley \& Sons; 1996.

60. Backman K, Ptashne M, Gilbert W. Construction of plasmids carrying the $\mathrm{Cl}$ gene of bacteriophage lambda. Proc Natl Acad Sci U S A. 1976;73(11):41748.

61. Figurski DH, Helinski DR. Replication of an origin-containing derivative of plasmid RK2 dependent on a plasmid function provided in trans. Proc Natl Acad Sci U S A. 1979;76(4):1648-52.

62. Altschul SF, Gish W, Miller W, Myers EW, Lipman DJ. Basic local alignment search tool. J Mol Biol. 1990;215(3):403-10.

63. Rutherford K, Parkhill J, Crook J, Horsnell T, Rice P, Rajandream M-A, et al. Artemis: sequence visualization and annotation. Bioinformatics. 2000;16(10): 944-5.

64. Lorenz C, Hausner J, Büttner D. HrcQ provides a docking site for early and late type III secretion substrates from Xanthomonas. PLoS One. 2012;7(11): e51063.

65. Engler C, Kandzia R, Marillonnet S. A one pot, one step, precision cloning method with high throughput capability. PLoS One. 2008;3(11):e3647.

66. Ballvora A, Pierre M, van den Ackerveken G, Schornack S, Rossier O, Ganal M, et al. Genetic mapping and functional analysis of the tomato Bs4 locus governing recognition of the Xanthomonas campestris pv. vesicatoria AvrBs4 protein. Mol Plant-Microbe Interact. 2001;14(5):629-38.

67. Marois E, Van den Ackerveken G, Bonas U. The Xanthomonas type III effector protein AvrBs3 modulates plant gene expression and induces cell hypertrophy in the susceptible host. Mol Plant-Microbe Interact. 2002;15(7): 637-46.

68. Hermjakob $H$, Apweiler $R$. The proteomics identifications database (PRIDE) and the ProteomExchange consortium: making proteomics data accessible. Expert Rev Proteomics. 2006;3(1):1-3.

69. Deutsch EW, Csordas A, Sun Z, Jarnuczak A, Perez-Riverol Y, Ternent T, et al. The ProteomeXchange consortium in 2017: supporting the cultural change in proteomics public data deposition. Nucleic Acids Res. 2017:45(D1): D1100-6.

\section{Submit your next manuscript to BioMed Central and we will help you at every step:}

- We accept pre-submission inquiries

- Our selector tool helps you to find the most relevant journal

- We provide round the clock customer support

- Convenient online submission

- Thorough peer review

- Inclusion in PubMed and all major indexing services

- Maximum visibility for your research

Submit your manuscript at www.biomedcentral.com/submit 